УДК 635.92.055:582.097:001.32(470.13-25)

doi: 10.31140/j.vestnikib.2018.3(205).2

\title{
ВИДЫ ДРЕВЕСНЫХ ЛИАН В КОЛЛЕКЦИИ БОТАНИЧЕСКОГО САДА ИНСТИТУТА БИОЛОГИИ КОМИ НЦ УРО РАН
}

\author{
Л.Г. Мартынов \\ Федеральное государственное бюджетное учреждение науки \\ Институт биологии Коми научного центра Уральского отделения РАН, Сыктывкар \\ E-mail: martynov@ib.komisc.ru
}

\begin{abstract}
Аннотация. Представлены результаты испытания в ботаническом саду Института биологии в Республике Коми видов древесных лиан, привлеченных в интродукцию сравнительно недавно. Приведены сведения о биологии роста, развития и зимостойкости 18 видов и форм растений, относящихся к 10 семействам. Установлено, что многие древесные лианы обладают быстрым ростом, привлекательными декоративными свойствами, но недостаточно зимостойки. Для использования в озеленении рекомендованы около 10 видов и форм древесных лиан.
\end{abstract}

Ключевые слова: Республика Коми, интродукция, древесные лианы, вегетация, рост побегов, зимостойкость

\section{Введение}

Подбором ассортимента растений для озеленения в Республике Коми многие годы занимаются специалисты отдела Ботанический сад Института биологии Коми НЦ УрО РАН. Район, где проводятся интродукционные исследования, находится в 8 км к югу от г. Сыктывкара и входит в подзону средней тайги. Условия данного района достаточно благоприятны для произрастания многих видов древесных экзотов. В последние годы в Республике Коми происходят изменения, свидетельствующие о потеплении климата. Это подтверждает и улучшение общего состояния древесных растений, интродуцированных в ботаническом саду (Мартынов, 2013). Те виды, которые не были способны расти здесь 20-30 лет тому назад, в настоящее время проявляют достаточно высокую зимостойкость и находят применение на участках садоводов-любителей.

В ботаническом саду Института биологии собрана коллекция, включающая около 550 таксонов древесных растений, половина из них привлечена в интродукцию в течение последних 20 лет. Преобладающей жизненной формой в коллекции являются кустарники, которые составляют около 80 \% всего состава растений. Небольшим количеством таксонов представлены вьющиеся кустарники, или древесные лианы. Раннее вступление кустарников в генеративный период развития позволяет в течение сравнительно небольшого срока наблюдений дать оценку их перспективности для использования в озеленении. Древесные лианы имеют ряд преимуществ перед вьющимися травянистыми растениями. Весной они быстро покрываются зеленью, обильно цветут и плодоносят, давая съедобные или декоративные плоды. В большинстве своем лианы долговечны, обладают сильным ростом, разнообразной формой, величиной и строением густого листового покрова, а также красивой окраской листьев осенью. К сожалению, древесные лианы пока крайне редко используются в декоративном са- доводстве Республики Коми. Причиной малого распространения этих растений в посадках является недостаточная изученность многообразия видов и отсутствие посадочного материала, устойчивого к неблагоприятным условиям среды.

\section{Материал и методы}

Материалом для наблюдений послужили древесные лианы 18 видов и форм, относящихся к 12 родам и 10 семействам. Возраст большинства образцов составлял 10-15 лет. Наблюдения за ходом роста и развития растений проводили в течение 12 лет, с 2006 по 2017 г. Кроме того, принимали во внимание результаты исследования растений прошлых лет. Использовали общепринятую методику фенологических наблюдений, применяемую во многих ботанических садах России (Методика ..., 1975). Зимостойкость древесных лиан оценивали визуальным способом по степени обмерзания побегов и их общему состоянию. Различали три степени обмерзания: сильную (обмерзает вся надземная часть побегов), среднюю (надземная часть побегов обмерзает наполовину) и слабую (обмерзает верхушечная часть побегов).

\section{Результаты и обсуждение \\ Семейство Actinidiaceae Hutch. - Актиниди- евые.}

Actinidia arguta (Siebold et Zucc.) Planch. ex Miq. - Актинидия острая. В естественных условиях растет на юге Дальнего Востока, в Корее и Японии. Одна из высокорослых древесных лиан. На родине актинидия острая выдерживает морозы до $-45 \ldots-50{ }^{\circ} \mathrm{C}$, но в средней полосе европейской части России нередко обмерзает (Колесников, 1974).

В ботаническом саду актинидию острую изучают с 2005 г. Из семян, полученных из Тарту (Эстония), выращены 2 экз. Состояние растений оценивается как удовлетворительное. Побеги актинидии, ежегодно мощно отрастая в длину на 0.8-1.5 м, в зимний период обмерзают либо на- 
половину, либо до корневой шейки. Начало отрастания отмечено в конце третьей декады мая, рост продолжается до глубокой осени. Актинидия острая имеет плотные листья удлиненноовальной формы с короткой острой верхушкой и клиновидным основанием длиной 8-15 см. Растения не цветут и не плодоносят. Учитывая продолжительную сохранность растений в ботаническом саду, изучение вида следует продолжить, мобилизуя более разнообразный интродуцируемый материал.

A. kolomikta (Maxim.) Maxim. - Актинидия коломикта. Родина вида - Дальний Восток, Япония и Китай. Древесная лиана высотой до 8-10 м. Листья тусклые тонкие, иногда неравнобокие, чаще яйцевидной формы, длиной 8-10 см. Растение двудомное. Мужские экземпляры имеют цветки, собранные в соцветия по 12-17 шт., цветки женских экземпляров расположены по одному или по два-три. Актинидия коломикта считается самым зимостойким среди видов рода. Растет медленнее актинидии острой. Не переносит сухости воздуха и почвы (Колесников, 1974).

В ботанический сад актинидия коломикта впервые поступила в 1983 г. из Москвы в виде укорененных черенков. Несмотря на солнечное местоположение и сухость почвы, растения ежегодно мощно отрастают, образуя побеги длиной 1.21.8 м, которые после перезимовки обычно обмерзают наполовину. Высота кустов без опор не превышает 1 м. В генеративную фазу развития растения вступили на шестой год выращивания. Они цветут, но плодов не завязывают, так как представ.лены только женскими особями. В 2012 г. на отдельных цветках наблюдали завязывание плодов, но они до конца не развились и рано опали. За 30 лет высота растений не изменилась, при этом диаметр корневой шейки достиг $12 \mathrm{cm.}$

Лучшее состояние имеют растения (10 экз.), выращенные из семян, поступивших в 1997 г. из Москвы. Начало вегетации по многолетним данным отмечено в середине мая - 16 . V (10.V-25.V). Одновременно с распусканием почек начинается рост побегов, который не прекращается до глубокой осени. Длина прироста главных побегов, отросших от корневой шейки, за сезон может достигать 65-100 см, боковых - 16-42 см. Растения растут без опоры, длинные побеги на высоте 0.75 м ниспадают на землю, принимая дугообразную форму. Побеги одревесневают на 45-75 \% их длины. Листья обычно опадают после наступления заморозков в середине октября, не меняя окраски. Среди растений имеются как мужские, так и женские особи. Цветение актинидии коломикта зафиксировано в начале второй декады июня. Цветки довольно крупные (до 1.8 см в диаметре), чисто белые, по форме напоминают цветки яблони. Окончание цветения происходит в конце второй декады июня, цветки осыпаются одновременно. К середине августа формируются плоды цилиндрической формы, которые долго сохраняют свою твердость. Средние по размеру плоды имеют длину 17 мм, ширину 13 мм, а самые крупные - 25 и 15 мм соответственно. Окраска плодов изумрудно-зеленая, проявляется не каждый год. Плоды созревают (становятся мягкими) с приходом первых заморозков, обычно 8.IX (25.VIII-15.IX). Семена полноценные. Актинидия коломикта в условиях сада не подвержена выпреванию (отслаиванию коры на побегах), что нередко можно наблюдать у других дальневосточных видов, поэтому долго сохраняется в коллекции. Размножают актинидию летними черенками или посевом семян. Вид может быть рекомендован для культивирования в таежной зоне Республики Коми в первую очередь как ценное плодово-ягодное растение. В вертикальном озеленении использование актинидии затруднительно, так как из-за регулярного обмерзания верхушечной части побегов она не может подниматься по опорам выше $1.5 \mathrm{M}$.

\section{Семейство Aristolochiaceae Juss. - Кирказо-} новые.

Aristolochia manshuriensis Kom. - Аристолохия маньчжурская. Кустарниковая лиана высотой до 15 м. Распространена в южной части Приморского края, в Китае и Корее. Имеет крупные (длиной до $30 \mathrm{cм}$ ) листья округло-сердцевидной формы. Цветки по одному или два на коротких цветоножках свешиваются из пазухи листа. Цветок состоит из длинной изогнутой у основания трубки и широкого трехлопастного зеленоватожелтого отгиба. Плод - крупная шестигранная цилиндрическая коробочка. В средней полосе России аристолохия маньчжурская является не вполне зимостойким видом, поэтому рекомендована главным образом для использования в приусадебных садах (Александрова, 2001).

В ботаническом саду аристолохия маньчжурская выращена из семян, поступивших в 2009 г. из Липецкой области. Имеется одно растение, в семь лет высота его составила 1.8 м. Почти ежегодно большая часть отросших побегов обмерзает, в неблагоприятные зимы погибает и многолетняя часть побегов. Основание корневой шейки сохраняется. За лето отрастают новые побеги, достигающие длины 1.2 м. В генеративную фазу развития растение еще не вступило. Для более мощного развития аристолохии необходима богатая гумусом почва. Вид является очень декоративным и перспективным для дальнейшего изучения.

Семейство Caprifoliaceae Juss. - Жимолостные.

Lonicera $\times$ americana (Mill.) C. Косh - Жиимолость американская. Гибрид между видами жимолость каприфоль (L. caprifolium L.) и ж. тосканскал (L. etrusca Santi). Высокорослал полувечнозеленая лиана. Вид недостаточно зимостойкий, поэтому в средней полосе России требует укрытия на зиму. 
В ботаническом саду Института биологии Lonicera $\times$ americana изучают с 2009 г. Саженцы получены из Йошкар-Олы. Растения растут не на опорах. Побеги, отросшие в течение лета на длину 1.5 м, стелются по земле. Несмотря на то, что побеги зимуют под естественным снежным покровом, каждый год у них обмерзают однолетние приросты, а в неблагоприятные зимы (20142015 гг.) - и многолетние. На побегах разного возраста часто происходит отслаивание коры. Отрастание побегов у гибрида начинается уже в середине мая, но их рост не завершается. В условиях Республики Коми жимолость американская для интродукции непригодна.

Lonicera caprifolium L. - Эиимолость каприфоль. Растет на Кавказе, в Закавказье, в центре и на юге Европы. Вьющийся кустарник высотой до 3-5 м. Листья плотные, кожистые, широкоэллиптические, длиной 4-10 см, сверху темнозеленые, снизу сизые. Верхушечные две-три пары листьев срастаются своими основаниями, образуя сплошную манжетку вокруг побега. Венчик цветка длиной 3-5 см, желтовато-белый, иногда со слабым пурпурным оттенком. Плоды - оранжево-красные ягоды. Растет довольно быстро. Обильно цветет лишь на освещенных местах.

В ботанический сад жимолость каприфоль привлекали для изучения неоднократно. В 1955 г. из Ленинграда были завезены 6 экз. растений, затем в 1978 г. три саженца из природных мест обитания (район г. Туапсе), и в 1995 и 1997 гг. поступили шесть экземпляров из Йошкар-Олы и Уфы. Как показали наблюдения, растения характеризуются продолжительным ростом побегов и слабой зимостойкостью. Побеги, ежегодно отрастая на длину 0.8-1.2 м, во время перезимовки значительно обмерзали. Цветение отмечали не каждый год, плоды завязывались слабо. Регулярное обмерзание побегов и отсутствие дополнительного ухода привело к постепенному ослаблению растений и их гибели.

В настоящее время в саду успешно растут растения, полученные в 2008 г. из Санкт-Петербурга в виде саженцев. Кроме того, имеется белая форма жимолости (Lonicera caprifolium 'Alba'), приобретенная в виде саженцев в Москве в 2006 г. Состояние растений обоих образцов хорошее. ЗЖимолость каприфоль в условиях интродукции характеризуется ранним началом развития (середина мая) и поздними сроками сбрасывания листьев при наступлении устойчивых отрицательных температур (конец октября). Рост побегов у вида полностью не завершается. Цветут растения ежегодно и достаточно обильно. Цветение начинается в среднем 15.VI (8.VI-20.VI) и продолжается в течение двух недель. Во время цветения растения исключительно декоративны. Плоды завязываются не на всех цветках, массовое их созревание наблюдается в середине августа. У белоцветковой формы цветение начинается на неделю раньше, плоды не завязываются. Для обоих образцов жимолости установлены низкие опоры, так как выше снеговой линии побеги обмерзают. При культивировании растений на высоких опорах плети на зиму необходимо опускать на землю. Легко размножается отводками, зелеными и одревесневшими черенками, делением кустов. Рекомендуется для озеленения по всей таежной зоне с использованием укрытия на зиму.

Lonicera periclymenum L. 'Serotina' - Жиимолость вьющаяся поздняя. Лиана до 3 м высотой. Имеет довольно крупные листья яйцевидной формы, темно-зеленые сверху и сизые снизу. Цветки двугубые снаружи пурпурные, внутри кремовобелые. В средней полосе цветет с конца июня до начала августа. Ягоды красные. Является одной из красивейших древесных лиан среди жимолостей. В Москве форма недостаточно зимостойкая (Древесные ..., 1975).

В ботанический сад жимолость вьющаяся поздняя поступила на изучение в 2009 г. из Кирова в виде саженцев. Растения культивируют на низких опорах. Выше линии снегового покрова побеги обмерзают. Растения не цветут. Для лучшего развития им необходим дополнительный уход. Форма представляет интерес для дальнейшего изучения.

Lonicera prolifera (Kirchn.) Rehder - Зћимолость отпрысковая. Происхождение - восток Северной Америки. Лиана высотой 3-4 м. Растет быстро. Листья крупные, эллиптические или обратнояйцевидные, до $9 \mathrm{~cm}$ длиной и 5.5 см шириной, ярко-зеленые сверху, сизые снизу. Верхние две пары листьев срастаются в толстоватые плоские диски. Цветки мелкие в колосовидных соцветиях по 2-4 шт., ярко-желтые. Плоды округлые красные, собранные в крупные соплодия, созревают в сентябре. В Москве зимостойкость полная (Древесные ..., 1975).

В ботанический сад на изучение вид поступил в 2005 г. в виде саженцев из Чебоксар. Основные фенологические фазы роста и развития следующие: начало распускания листьев - $10 . \mathrm{V}$, начало роста побегов - $15 . \mathrm{V}$, окончание роста - 5.VIII, массовое цветение - 25.VI, массовое созревание плодов - 10.IX. Листья опадают в конце октября, не меняя окраски. В условиях сада вид оказался наиболее зимостойким среди вьющихся жимолостей. На опорах растения достигают высоты 2.2 м. Обмерзают только концы однолетних приростов, не успевших завершить рост. Побеги, не несущие на концах соцветия, за сезон отрастают в длину на 85-105 cм, а побеги с соцветиями - на 22-35 см. Отличается крупными листовыми пластинками длиной до 13 см, шириной 11 см. Цветки неяркие, оранжево-желтые диаметром 1.0-1.5 см, собраны в небольшие соцветия по 2-7 шт. (фото 1). В одном соплодии чаще образуются по два плода ярко-оранжевой окраски. Высокая зимостойкость и декоративность 
жимолости отпрысковой позволяет рекомендовать ее для использования в вертикальном озеленении по всей таежной зоне Республики Коми.

Семейство Celastraceae R. Br. - Бересклетовые.

Tripterygium regelii Sprague et Takeda - Tpexкрыльник Регеля. Происходит из Восточной Азии. Высоко поднимающаяся древесная лиана с коричнево-красными побегами. Имеет крупные широкоэллиптические листья до 15 см длиной. Цветки мелкие, до 8 мм в диаметре, многочисленные, желтовато-белые, собраны в конечные метелки до 20 см длиной. Плоды - зеленовато-белые коробочки до 1.5 см длиной, снабжены тремя крылышками. Культивируется преимущественно в ботанических садах. В Москве проявляет достаточно высокую зимостойкость, рекомендуется для озеленения (Плотникова, 2011).

В дендрарии ботанического сада имеется 1 экз., поступивший из Йошкар-Олы в 2009 г. Развитие растения проходит очень медленно, так как оно испытывает недостаток света. В семь лет его высота составила 32 см. Растение зимует под естественным снеговым покровом без повреждений. Отличается ранним началом и поздним окончанием вегетации. Представляет интерес для дальнейшего изучения.

\section{Семейство Hydrangeacea Dumort. - Гортен-} зиевые.

Hydrangea heteromalla D. Don - Гортензия черешковая. Вьющийся кустарник высотой до 25 м с голыми коричневыми побегами, покрытыми воздушными корнями. Происходит из южных районов Сахалина, Японии и Китая. Листья широкояйцевидные, 5-10 см длиной, сердцевидные, у основания темно-зеленые, блестящие. Черешки листьев длиной 2-8 см. Соцветия щитковидные, 15-25 см в диаметре, с бесплодными белыми краевыми цветками до $3 \mathrm{~cm}$ в диаметре. Является высоко зимостойкой древесной лианой в средней полосе России (Заливский, 1956).

В ботанический сад гортензия поступила в виде укорененных черенков в 2009 г. из Кирова. Растения стелются по земле, так как растут не на опорах. Отличаются быстрым ростом и высокой зимостойкостью. Прирост побегов за вегетационный период составляет 12-22 см. В генеративную фазу развития растения еще не вступили. Почки начинают распускаться в середине мая, листья опадают в середине октября. Перспективный вид для выращивания в Республике Коми. Изредка встречается на садовых участках у любителей.

Семейство Menispermaceae Juss. - Луносемянниковые.

Menispermum canadense L. - Луносемянник канадский. Происходит из Северной Америки.
Полукустарниковая лиана высотой до 5 м. Побеги тонкие, обвивающиеся вокруг опоры. Листья округлые, 6-12 см в поперечнике, с заостренными тремя-пятью лопастями на черешках, с широко выемчатым основанием, светло-зеленые. Цветки зеленовато-желтые, в коротких метельчатых соцветиях на тонких цветоножках. Плоды круглые, сине-черные костянки до 8 мм в диаметре. Растение двудомное. Луносемянник канадский является редким растением в ботанических садах северных регионов. Издавна растет в дендрологическом саду им. В.Н. Нилова в Архангельске, где обмерзает (Демидова, 2013).

Вид поступил в сад на изучение в 1991 г. из Москвы в виде саженцев. На протяжении длительного срока наблюдений показывает достаточно высокую зимостойкость. Каждый год растения поднимаются по опоре на высоту до $2.5 \mathrm{~m}$, зимой происходит обмерзание побегов примерно на 70 \% их длины. Побеги начинают отрастать в третьей декаде мая, рост продолжается до глубокой осени. Несмотря на то, что рост не завершается, осенью листья приобретают золотисто-желтую окраску и постепенно опадают. Ежегодно в первой декаде июня цветет в течение двух недель, но плоды не образуются. Дает многочисленную корневую поросль, с помощью которой легко размножается. Луносемянник канадский можно рекомендовать для использования в озеленении южных и центральных районов Республики Коми для декорирования заборов, устройства беседок, арок.

Menispermum dauricum DC. - Л. даурский. Вил встречается в Восточной Сибири, на Дальнем Востоке, на северо-востоке Китая, в Японии и Корее. Полукустарниковая лиана до 4 м высотой. В ботаническом саду изучается с 2002 г. Вид представлен тремя образцами. По морфологическому описанию и биологии развития имеет большое сходство с луносемянником канадским, но отличается от него замедленным ростом. Применение в зеленом строительстве такое же, как и M. canadense.

Семейство Ranunculaceae Juss. - Лютиковые.

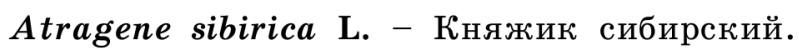
Вьющийся кустарник с тонкими сероватыми побегами до 5 м длиной, обвивающий опоры черешками своих листьев. Сибирский вид. Встречается на всей территории Республики Коми. Найдены экземпляры с голубыми чашелистиками (Флора ..., 1976).

В саду княжик сибирский впервые был выращен из семян, полученных из Ленинграда в 1976 г. Имеются также растения, выкопанные в лесу. Лиана отличается ранним началом и окончанием вегетации (первая декада мая-середина сентября). Рост побегов завершается уже в конце июня. Прирост побегов за сезон составляет 2832 см. Цветет очень обильно с начала июня в 
течение 10 дней бело-кремовыми поникающими одиночными цветками колокольчатой формы (фото 2). Декоративны также пушистые серебристые плоды, собранные в шаровидные головки, которые созревают в августе. Дает незначительный самосев. Княжик сибирский хорошо растет и развивается на влажных и удобренных почвах. Его культивирование возможно даже в районе Воркуты, но там растения следует размещать в местах, защищенных от северных ветров. Это одна из самых выносливых и декоративных лиан, к сожалению, не нашедшая достойного применения в посадках северных городов.

\section{Семейство Schisandraceae Blume - Лимонни- ковые. \\ Schisandra chinensis (Turcz.) Baill. - Лимон-} ник китайский. Растет в Приморском крае, на Сахалине, в Японии и на севере Китая. На родине плети лимонника могут достигать длины 10 12 м и больше, в культуре - 4-6 м. Побеги розовато-коричневые. Листья эллиптические, яркозеленые сверху, с прозрачными точками, 7-10 cм в длину, на красноватых черешках. Цветки раздельнополые, некрупные, бледно-розовые или желтовато-белые, обладают приятным ароматом, находятся по одному-четыре на длинных розоватых цветоножках. Ягоды оранжево-красного цвета, собраны в изящные гроздья, съедобные, обладают ценными свойствами.

Впервые растения лимонника китайского поступили в сад на изучение в 1984 г. Из Ленинграда было завезено три саженца, развитие которых проходило успешно. $\mathrm{B}$ семь лет на опорах растения достигали высоты 1.2 м. В девять лет отмечено первое цветение. Цвели растения неежегодно, с середины июня в течение двух недель, завязывания плодов не происходило. Почки распускались в середине мая, рост побегов заканчивался на большей части кроны в первой половине июля. Ежегодный прирост составлял 25-35 см. В конце сентября-начале октября листья приобретали золотисто-желтую окраску и есте-

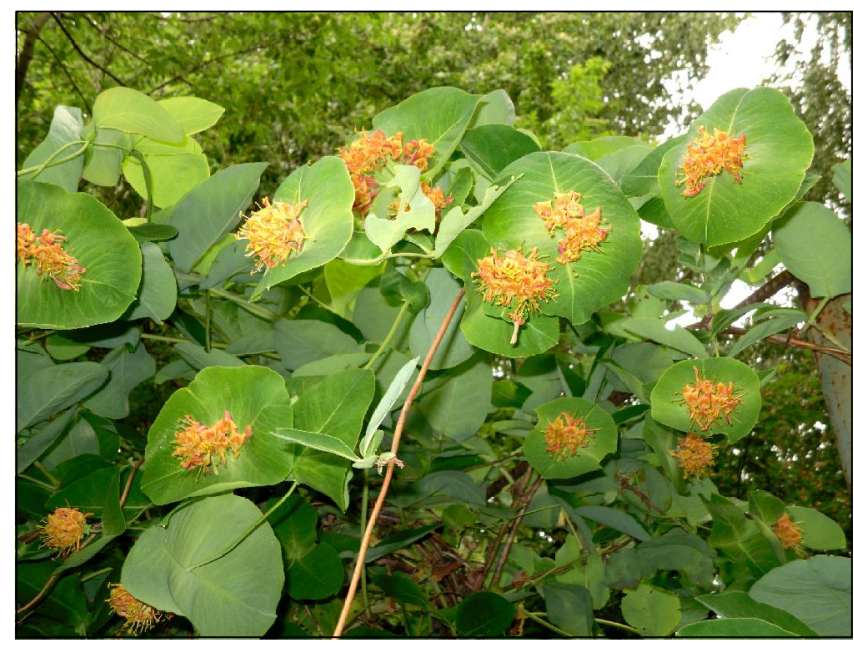

Фото 1. Lonicera prolifera в цветении. ственно опадали. Почти каждый год происходило обмерзание концов однолетних побегов, в суровые зимы - многолетних (до уровня снегового покрова). Признаков выпревания у растений не было. До настоящего времени растения старших возрастных групп данного образца не сохранились. Имеются молодые растения, выращенные из корневых отпрысков. Кроме того, в коллекции на изучении находятся растения лимонника, поступившие саженцами в 2004 г. из Риги (Латвия), их состояние хорошее.

Лимонник китайский в условиях района Сыктывкара проявляет достаточно высокую зимостойкость, его можно рекомендовать для ограниченного использования, в основном как плодовоягодное растение. Для получения плодов необходимо в посадках иметь как мужские, так и женские особи. Лучшего развития растения достигают на плодородных почвах с хорошим дренажом.

Семейство Solanaceae Juss. - Пасленовые.

Solanum dulcamara L. - Паслен сладко-горький. Родина - Европа, Северная Африка. В лесах южных районов Республики Коми растет по заливным берегам рек и озер. Изредка его выращивают в регионе в приусадебных садах. В культуре - полукустарник с вьющимися стеблями высотой до $1.8 \mathrm{~m}$.

В дендрарии ботанического сада изучается с 2007 г. Имеются растения, взятые из природы и выращенные из семян местной репродукции. Они отличаются быстрым ростом, на опорах в течение двух сезонов достигают предельной высоты 1.8 м. Кусты разрастаются в ширину медленно, так как из года в год в кроне происходит отмирание трехлетних побегов и отрастание новых. Начало вегетации у вида отмечается во второй декаде мая, окончание - в третьей декаде сентября. Рост побегов непродолжительный - до 60 дней. Цветение отмечается с третьей декады июня и продолжается в течение двух недель. Плоды созревают в августе. Наблюдается самосев. Вид с темно-зелеными яйцевидными листьями, светло-лиловы-

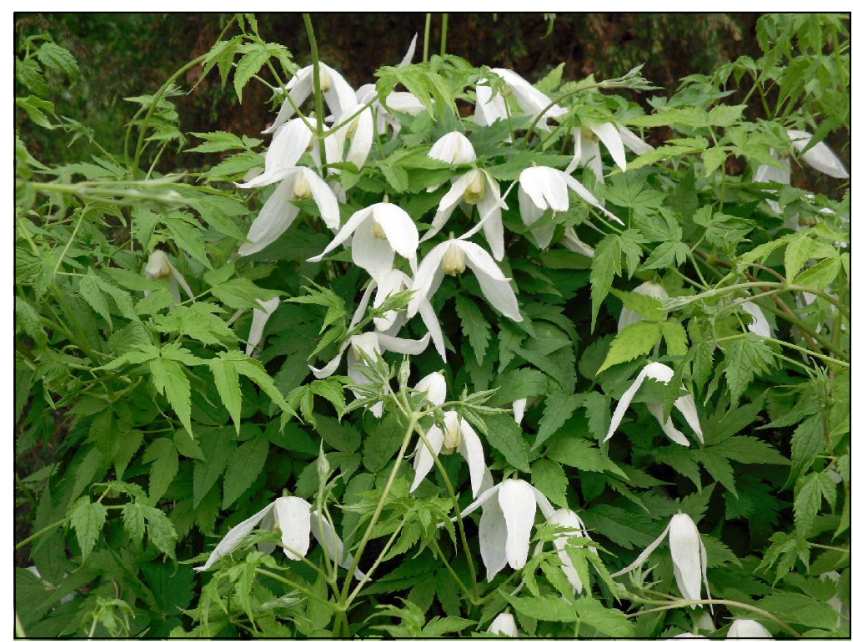

Фото 2. Atragene sibirica в цветении. 
ми цветками и ярко-красными плодами-ягодами, собранными в кисти, декоративен в посадках.

Паслен сладко-горький очень легко размножается семенами, отпрысками и черенками. При осеннем посеве семян в открытый грунт весной появляются дружные всходы, а к осени сеянцы уже зацветают. Вид можно рекомендовать для вертикального озеленения малых садов по всей территории Республики Коми.

\section{Семейство Vitaceae Juss. - Виноградовые.}

Ampelopsis brevipedunculata (Maxim.) Trautv. Виноградовник короткоцветоножковый. Произрастает на Дальнем Востоке, севере Кореи, северо-востоке Китая. Лиана до 20 м высотой. Имеет широкоовальные трехлопастные листья длиной 6-12 см. В ботанический сад вид был привлечен в виде саженца из Сочи в 2001 г. В питомнике на протяжении пяти лет состояние растения оценивали как удовлетворительное. Ежегодно происходило обмерзание однолетних побегов практически до уровня корневой шейки, затем восстановление за счет отрастания новых. Высота растения на опоре не превышала 0.8 м. После пересадки в дендрарий состояние растения значительно ухудшилось, через пять лет оно погибло. Для интродукции в Республике Коми вид является неперспективным.

Parthenocissus quinquefolia (L.) Planch. - Девичий виноград пятилисточковый. Его родина восток Северной Америки. Плети девичьего винограда могут достигать длины 20-25 м. Листья кожистые, темно-зеленые, пальчато-сложные, с пятью листочками, очень декоративные. Усики с пятью-восемью разветвлениями оканчиваются дисковидными присосками. Плоды (ягоды) мелкие, черные, несъедобные. В средней полосе России вид получил самое широкое распространение в вертикальном озеленении. В Республике Коми девичий виноград в городском озеленении начали культивировать только в последние годы.

В дендрарии ботанического сада на изучении находится несколько образцов. По некоторым морфологическим признакам растения отличаются между собой, но зимостойкость у них примерно одинаковая. После неблагоприятных зимних условий (2009-2010, 2014-2015 гг.) у всех растений почти до основания вымерзли многолетние побеги. Такую же степень обмерзания наблюдали у растений в посадках г. Сыктывкара. Через два года благодаря быстрому росту они полностью восстанавливали свои первоначальные размеры (фото 3). Девичий виноград начинает рост в поздние сроки - в конце мая-начале июня и не завершает его полностью. Тем не менее, почти каждую осень происходит естественное сбрасывание листьев, которые в это время года приобретают ярко малиновую окраску. У одного из образцов наблюдается регулярное цветение (с начала июня до середины августа) и в редкие годы плодоношение (конец сентября). Плоды сохраняются зелеными, но семена вызревают полностью.

За относительную зимостойкость, быстрый рост и декоративную листву девичий виноград пятилисточковый рекомендуется для вертикального озеленения стен, беседок, балконов, оград в южных и центральных районах Республики Коми. Лучшего развития растения достигают в защищенных местоположениях на плодородных хорошо дренированных почвах. Вид теневыносливый.

Vitis amurensis Rupr. - Виноград амурский. Растет на Дальнем Востоке, на северо-востоке Китая, севере Кореи. Лиана поднимается по опорам с помощью усиков на высоту до 22 м. Листья крупные, широкояйцевидные, длиной 1225 см, глубоко трех-пятилопастные, темно-зеленые, морщинистые. Растение обычно двудомное, но встречаются особи с обоеполыми цветками. Цветки мелкие, желтоватые, собраны в сложные кисти. Плоды шаровидные до 1.2 см в диаметре, фиолетовые или синие, съедобные. Один из наиболее северных и зимостойких видов. На родине выдерживает морозы до $-40{ }^{\circ} \mathrm{C}$, хорошо зимует и плодоносит в Ленинграде (Колесников, 1974).

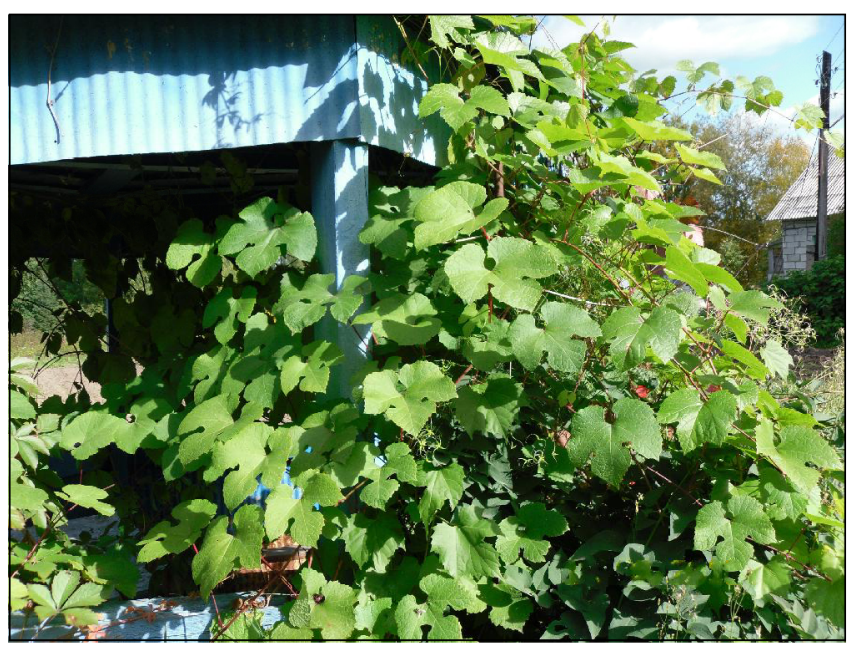

Фото 4. Vitis amurensis.

Фото 3. Parthenocissus quinquefolia. 
Изучение винограда амурского в ботаническом саду проводили еще в 1946 г. Было завезено пять саженцев из Липецкой области. В возрасте пяти лет они имели высоту 1.2 м. Ежегодно у растений происходило обмерзание побегов до корневой шейки, что, в конечном счете, привело к их гибели. В настоящее время имеется образец, выращенный из семян, полученных в 1994 г. из Белой Церкви (Украина). Растения содержат на опорах. Каждый год побеги отрастают на высоту до 1.8 м, одновременно с ростом центральных побегов образуются и боковые. Благодаря этому к концу вегетационного сезона создается стенка с красивой лиственной мозаикой (фото 4). После перезимовки однолетние приросты обмерзают практически полностью. Начало вегетации у винограда амурского отмечено с третьей декады мая с момента отрастания побегов, листья не опадают. Почти ежегодно с третьей декады июня происходит цветение, но плоды не завязываются. Виноград амурский в местных условиях не подвергается выпреванию, поэтому растет на одном месте длительное время. На это положительное свойство вида обратила внимание 3.И. Лучник (1970) при интродукции в Алтайском крае. В Республике Коми культура винограда амурского возможна для ограниченного применения, преимущественно в любительских садах. На зиму его побеги необходимо опускать на землю и утеплять.

\section{Заключение}

Из 18 видов и форм древесных лиан, находящихся на изучении в ботаническом саду Института биологии, выявлено около 10 , отличаютцихся достаточно высокой зимостойкостью, способных после обмерзания быстро восстанавливаться, цвести и плодоносить, не теряя при этом декоративных свойств, и длительное время сохранять свою жизнеспособность. Они могут найти применение в озеленении, главным образом, в южных и центральных районах Республики Ко- ми. Для широкого использования можно рекомендовать Atragene sibirica, Parthenocissus quinquefolia, Lonicera prolifera, Menispermum canadense и $M$. dauricum, Solanum dulcamara, для ограниченного - Lonicera caprifolium, Hydrangea heteromalla, Schisandra chinensis, Vitis amurensis, Actinidia kolomikta.

Работа проводилась на базе УНУ «Научная коллекиия живых растений" Ботанического сада Института биологии Коли НЦ УрО РАН, рег. нолер 507428. Исследования выполнены в ралках государственного задания по теле «Закономерности процессов репродукиии ресурсных растений в культуре на европейском Северо-Востоке» № AAAA-A17-117122090004-9.

\section{ЛИТЕРАТУРА}

Александрова, М. С. 100 лучших растений для вашего сада / М. С. Александрова. - Москва : Фитон+, 2001. -272 с.

Демидова, Н. А. Каталог коллекции древесных растений дендрологического сада им. В. Н. Нилова Федерального бюджетного учреждения "Северный научно-исследовательский институт лесного хозяйства" / Н. А. Демидова, Т. М. Дуркина ; отв. ред. Н. А. Демидова. - Архангельск, 2013. - 3-е изд. - 142 с.

Древесные растения Главного ботанического сада АН СССР. - Москва : Наука, 1975. - 547 с.

Заливский, И. Л. Декоративные кустарники / И. Л. Заливский. - Москва, 1956. - 208 с.

Колесников, А. И. Декоративная дендрология / А. И. Колесников. - Москва: Лесная промышленность, 1974. - 704 c.

Лучник, З. И. Интродукция деревьев и кустарников в Алтайском крае / З. И. Лучник. - Москва : Колос, 1970 . - $665 \mathrm{c}$.

Мартынов, Л. Г. О зимостойкости древесных растений, интродуцированных в ботаническом саду Института биологии Коми НЦ УрО РАН / Л. Г. Мартынов // Бюллетень Главного ботанического сада. 2013. - Вып. 199, № 1. - С. 19-26.

Методика фенологических наблюдений в ботанических садах СССР. - Москва : Изд-во АН СССР, 1975. 27 c.

Плотникова, Л. С. Декоративные деревья, кустарники и лианы / Л. С. Плотникова. - Москва, 2011. $128 \mathrm{c}$.

Флора северо-востока европейской части СССР. Ленинград : Наука, 1976. - Т. 3. - 296 с.

\title{
THE SPECIES OF WOODY LIANAS IN COLLECTION OF THE BOTANICAL GARDEN OF THE INSTITUTE OF BIOLOGY OF THE KOMI SCIENCE CENTER
}

\author{
L.G. Martynov \\ Institute of Biology of Komi Scientific Centre of the Ural Branch of the Russian Academy of Sciences, Syktyvkar
}

\begin{abstract}
There are experimental results on woody lianas which have been recently introduced in the Botanical Garden of the Institute of Biology (Komi Republic). The paper contains data on growth biology, development, and winter hardiness of 18 species and varieties of plants belonging to 12 genera and ten families. Numerous woody lianas grow rapidly and are highly decorative but are not winter hardy enough. Shoots grow long but become frozen almost every winter. Next summer the pants form new shoots and quickly restore. Seven species flower and bear fruits. There are six species of woody lianas which are winter hardy enough to be recommended for broad planting in the Komi Republic as Lonicera prolifera, Menispermum canadense, $M$. dauricum, Parthenocissus quinquefolia, Atragene sibirica, and Solanum dulcamara. The latter two are local species. Lonicera caprifolium, Vitis amurensis, Schisandra chinensis, and Actinidia kolomikta are not winter hardy enough. Hydrangea heteromalla is understudied. They can be planted carefully mostly in private gardens. Schisandra chinensis and Actinidia kolomikta should be used mainly as valuable fruit and berry plants.
\end{abstract}

Key words: Republic of Komi, introduction, woody lianas, vegetation, growth of shoots, winter hardiness 